\title{
Collaborative Quality Management
}

\author{
Goknur Arzu Akyuz \\ Attlom University \\ Turkey
}

\section{Introduction}

The challenges within the new business dynamics put higher expectations on visibility, velocity, accessibility and connectivity on supply chain partners (Akyuz \& Gürsoy, 2010; Zsidisin \& Ritchie, 2009). Nowadays, business organizations are facing with a global economic environment in which quick responses should be made to rapidly- changing customer requirements and the market environment (Yan et al., 2010, p.319), with an increasing levels of technological innovation and shrinkage of buying points in many markets (Williams et al., 2006, p.1273). Such a need for flexibility has brought together independent enterprises and increased the importance of supply chains to provide products or services in a more effective and flexible manner. Since these enterprises originate from various geographical locations, belonging to organizations with different interests, the coordination and integration of business processes involving all these independent enterprises becomes increasingly crucial to improve product and service quality to satisfy customers (Yan et al., 2010).

As competition moves beyond a single firm to the supply chain, QM (Quality Management) in the context of supply chain has started to attract more and more attention from researchers. As the focus is shifting from internal practices to the integration and assurance of processes spanning customers and suppliers, the integration of QM and supply chain topics has received additional importance for future competitiveness (Flynn \& Flynn, 2005; Foster \& Ogden, 2008; Kaynak \& Hartley, 2008; Matthews, 2006; Robinson \& Malhotra, 2005; Soltani et al., 2011). In this respect, the need for closer cooperation both internally (between functions) and externally (among partners), as well as new longer-term relationships have been considered as the key features in modern quality management by Williams et al., (2006).

Many literature items highlighted by Kuei et al., (2008) indicate that quality management practices are closely associated with improvements in supply chain performance as well as cumulative capabilities. Also, Flynn \& Flynn (2005) have empirically supported the need for integration of quality management practices with supply chain management and emphasised that organizations pursuing quality and supply chain goals simultaneously can achieve a competitive advantage that is difficult to imitate by other enterprises. They have provided clear support for the idea that organizations with stronger quality management practices achieve better supply chain performance. Kaynak \& Hartley (2008) also provide empirical support for the relationships among QM practices and performance measures, basing their premises on the confirmed relationships by Kaynak (2003) among the following constructs: 
- Supplier quality management

- Process management

- Quality performance

- Quality data and reporting

- Financial and market performance

- Management leadership

- Employee relations

- Training

- Product service design

- Inventory management performance

As the idea of "enterprise" evolves into the idea of "extended enterprise", traditional improvements within the enterprise proved to be insufficient in meet the challenges of the new era (Shao et al., 2006). In this context, information-sharing on product and processes quality within the supply chain framework is becoming a critical factor for quality improvement and competitiveness. In their review of literature for quality management and SCM, Robinson \& Malhotra (2005) clearly argue that quality practice should advance from traditional firm-centric, product-based mindset to an inter-organisational supply chain orientation involving customers, suppliers and other partners, while considering internal QM implementation as the prerequisite to supply chain quality. According to Yan et al., (2010, p.319) "satisfying customers can only take place when product quality, service and value are coupled at every node in the supply chain" and "quality management functions and activities should be taken beyond enterprise boundaries" . Similar ideas have also been mentioned by Flynn \& Flynn (2005); Lee et al., (2006); and Wiliams et al., (2006); clearly indicating that the new concept of quality needs to be broad, supply-centric and encompassing.

In line with these ideas, Rodrigues (2007) has developed the "quality organisation" framework and defined the "interdependant" behaviours of a quality organisation having the following main characteristics:

- $\quad$ responds to customer needs

- continually gathers and disseminates information

- cooperates and collaborates with internal and external units

- utilises participation, empowerment and a flat organisational structure

- implements on-going training and development

This definition also adds emphasis on the need for and the importance of dependancy, cooperation, collaboration and commitment among partners, and as such it is totally compatible with the "extended" view of the enterprise.

All of the forementioned arguments showed a need for new approaches and tools for quality management of today and of the future (Shao et al., 2006). Compounded with all the opportunities offered by the advances in IT and the increasing importance of the concepts of visibility and connectivity, the idea of "collaborative quality management" has been proposed in the literature as an extension of former philosophies of quality (Shao et al., 2006). Table 1 provided below is a clear depiction of this historical evolution in quality concepts on the way to collaborative quality management.

According to the table, four distinct stages stand out along this historical development. The first stage is characterised by a totally inspection-oriented approach with a focus on the production line. The second stage has a facility focus, with the use of Statistical Quality 


\begin{tabular}{|l|l|l|l|l|}
\hline \multicolumn{1}{|c|}{ Stage } & \multicolumn{1}{c|}{ Date } & \multicolumn{1}{c|}{ Scope } & \multicolumn{1}{c|}{ Focus } & \multicolumn{1}{c|}{ Main tools } \\
\hline $\begin{array}{l}\text { Quality } \\
\text { inspection }\end{array}$ & Before 1920's & Product line & Inspection & Measuring devices \\
\hline $\begin{array}{l}\text { Statistical Quality } \\
\text { control }\end{array}$ & $1930-1960^{\prime}$ s & Facility & Prevention & $\begin{array}{l}\text { Control charts, } \\
\text { Ishikawa diagram, } \\
\text { pareto analysis }\end{array}$ \\
\hline $\begin{array}{l}\text { Total Quality } \\
\text { Management }\end{array}$ & $1970-1990^{\prime}$ s & Enterprise & $\begin{array}{l}\text { Customer focus, } \\
\text { Design for } \\
\text { quality, Process } \\
\text { control }\end{array}$ & $\begin{array}{l}\text { Doe (Design of } \\
\text { Experiments), } \\
\text { QFD(Quality } \\
\text { Function } \\
\text { Deployment), } \\
\text { ISO 9000, Six Sigma }\end{array}$ \\
\hline $\begin{array}{l}\text { Collaborative } \\
\text { Quality } \\
\text { Management }\end{array}$ & 2000 's-future & Global & $\begin{array}{l}\text { Process } \\
\text { cooperation, } \\
\text { Systems } \\
\text { Integration, } \\
\text { Product lifecycle } \\
\text { Management }\end{array}$ & $\begin{array}{l}\text { The Internet, } \\
\text { Information } \\
\text { Technologies, } \\
\text { Enterprise } \\
\text { Application Systems }\end{array}$ \\
\hline
\end{tabular}

Table 1. Evolution of Collaborative Quality Management (Based on Shao et al., 2006)

Control techniques as its main characteristic. Enterprise-wide, systemic coverage of all the processes, customer-focus and the transition from "control" to "assurance" take place at stage three. Along with the ideas of "design for quality" and "excellence", use of the tools "DOE (Design of Experiments)", "QFD (Quality Function Deployment", "Six Sigma" and "Enterprise-wide Quality Management Systems (ISO 9000), correspond to this stage.

Globalisation, advances in IT and increased importance of process oriented, supply chaincentric approach bring us to the era of "collaborative quality management". Shao et al. (2006) emphasise the following in this regard:

- The need for coordinating the activities of quality management to deal with quality problems in real- time.

- The need for integrating the QM into business processess involving all supply chain partners to measure, analyse and continually improve products, services and processes to achieve the satisfaction of both internal and external customers.

Recently, Unherkal et al., (2010) have provided clear definitions for three significant quality dimensions required in collaborative quality management systems: the management, the assurance and the control aspects of quality. The main characteristics of each dimension are described below:

- Quality Management (QM) provides the strategic basis for quality for the transition towards a collaborative business, starting from the planning stages of the overall transition, and involving both the technical and managerial aspects of quality.

- Quality assurance (QA) specifically focuses on collaborative processes, their modeling, the quality of the models themselves, and ensuring error-prevention from a technical viewpoint.

- Quality control (QC) deals with the functions of actual data gathering and controlling, as well as the testing of the collaborative system, and as such it becomes both operational and tactical in nature. 
Shao et al., (2006) also emphasise that partners can collaborate throughout all the quality management processes, including quality control, assurance, improvement and auditting. This broad understanding covers collaboration at transactional (operational), tactical and strategic levels, including continuous, systemic, joint monitoring of the systems of supply chain partners to achieve overall improvements.

In line with this, Section 2 discusses the efforts to change towards such a collaborative quality management system, covering the existing efforts from both Quality Management and Supply Chain perspectives. Section 3 focuses on more recent efforts in developing new collaborative quality models.

\section{Inadequacies of the existing approaches and efforts to change}

There have been many discussions upto now as to the pitfalls and shortcomings of the available models.

Since the end of 1980s, the ISO 9000 norms have been increasingly recognised and accepted as a reference model for quality assurance (Romano 2002, p.981), being a systematic and process driven approach to quality assurance. However, there have been various critisisms in the related literature regarding the ISO 9000 standards, the most important ones of which are the perceived weakness in its ability to deliver real benefits, continued overemphasis on bureaucratic processes and documentation, as well as misapplications (Sroufe \& Curkovic, 2008). The literature also contains evidence supporting that no direct positive performance improvement can obtained by ISO registration as quoted by Sroufe \& Curkovic (2008, p.507) based on Johnson (2002) and Terziovsky et al., (2007). It is even argued that "ISO by itself does not provide competitive advantage" (Sroufe \& Curkovic, 2008, p.517).

The ISO systems are also critisised for not being supply-chain centric. ISO 9000:2000 revision definitely puts more emphasis on business results, customer relationship management, customer satisfaction, and long-term, mutually-beneficial supplier relationships, indicating efforts to look beyond the enterprise. However, it has been observed that most work on the ISO 9000 found throughout the literature are mainly centered around individual conpanies. Some of these works considered either the upstream side of the supply chain (supplier network) or the downstream one (demand network), while no study has been found concerning the impact of ISO 9000 on the supply chain as a whole (Romano, 2002). The idea of merging the views of upstream and downstream processes is also mentioned in Foster (2008). Soltani et al., (2011) have mentioned the qualitative investigations of the dynamics of supply chain quality management interventions to be rare, as well.

In this line of direction, Romano (2002) made an effort to analyse the impact of ISO 9000 adopting a supply chain perspective, clearly emphasising that there does not emerge any general agreement in the literature concerning the impact of ISO 9000 certification on the supply chain as a whole. The proposed framework of research takes into account the internal quality systems of the focal firms, suppliers and customers, as well as the relationship among these quality systems. This framework also ties up the quality systems of these different partners to the quality, cost, time, and volume flexibility performances of the focal firm.

Naturally, the need for the extension of current reference models to provide a supplycentric, broader and results-oriented view becomes evident. Nevertheless, it appears that efforts to integrate quality systems and supply chain are not yet complete.

Various quality excellence models, as well as performance measurement systems and quality award criteria are also critisised in the literature as "not being chain centric". 
Current excellence models definitely attach special importance to result orientation, customer focus, and partnership development. However, they tend to regard the intercompany interactions to be still at partnership level, and not yet at a level of web-based, full process collaboration among supply chain partners.

Kanji \& Wong (1999) and Kanji (2001) have already supported this idea, highlighting the need for the creation of a "cooperative quality culture", "managing all processes other than logistics","leadership" and "continunuous improvement" across the whole supply chain. In this direction, an "extended quality excellence model" for supply chain management is proposed, complying with the extended enterprise concept. Kanji's model is similar to EFQM (European Foundation for Quality Management) and emphasises the need for “extended TQM (Total Qality Management)".

Building upon on Kanji's Excellence Model, Wong (2003) developed a supply chain management excellence model, in which the concept of excellence is treated along the supply chain, and special importance is attached to the cooperative relationships. The ideas of customer focus, management by fact, continuous improvement and excellence are all treated across the supply chain partners, not merely for a single enterprise. The diagram provided in Figure 1 combines the ideas proposed by Kanji \& Wong (1999), Kanji (2001) and Wong (2003):

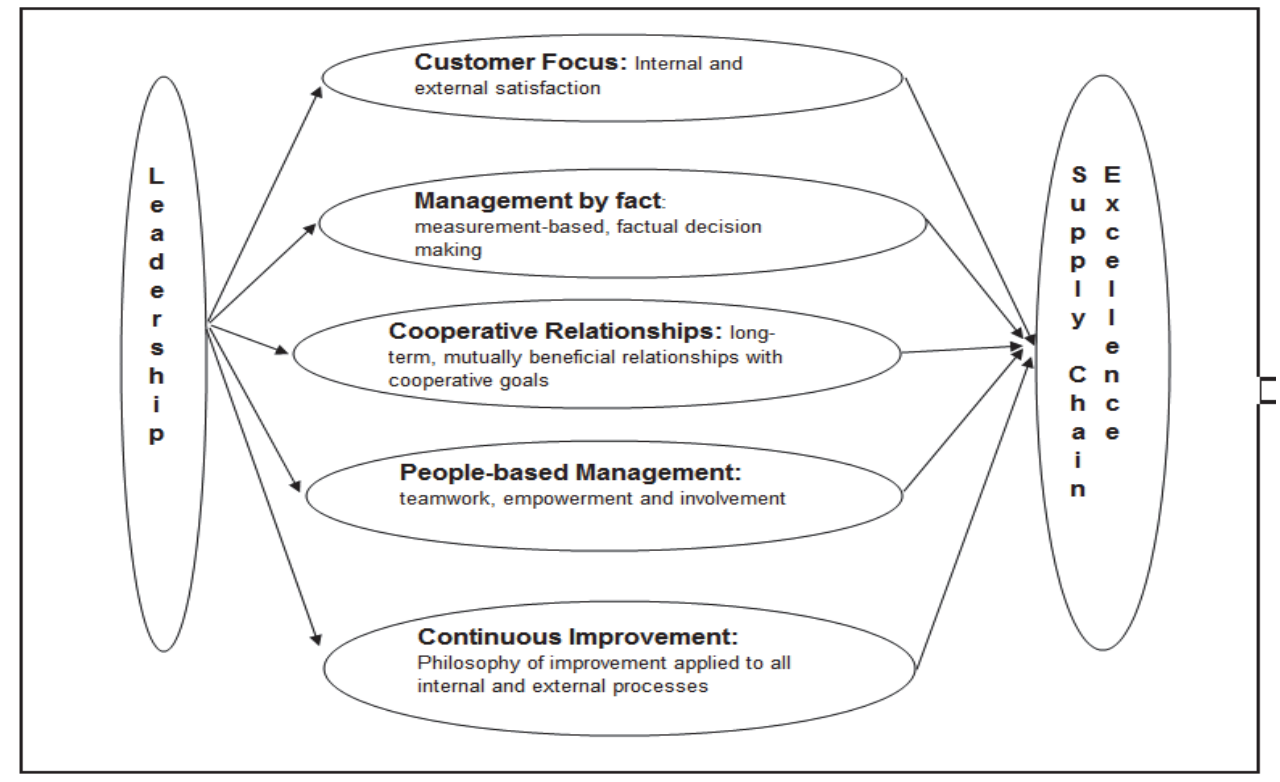

Fig. 1. Supply Chain Excellence Model, based on (Kanji \& Wong 1999), Kanji(2001) and Wong (2003)

In line with these ideas, Lee et al., (2006) also highlight the need for modernisation and changes in quality award criteria towards a more holistic and knowledge managementoriented perspective. It should be noted here that this critisism is despite the fact that ISO 9000:2000 revision incorporated several principles underlying the Malcolm Balridge National Quality Award criteria into the standard. 
Dror (2008) compares the BSC (Balanced Scorecard approach) against the existing quality award models, MBNQA (Malcolm Balridge National Quality award) and EFQM (European Foundation for Quality Management) based on high-level objectives, long-term programs, processes, targets and performance measures and feedback. The differences and limitations among these three models in Dror (2008)'s work are addressed in detail, and a fundamental difference among these structures is emphasised to be: "while the Balanced Scorecard, although implying a causal system hierarchy, is solely performance-oriented, MBNQA and EFQM emphasise cultural changes in the management of an enterprise (new leadership as a driver), using input variables in terms of system constructs and output variables in terms of operational and business results" (Dror 2008, p.592). Of the three frameworks, the Balanced Scorecard has been pointed out to have important advantages, such as having sequential objectives, the ability to support long-term programs, the potential to select relevant performance measures based on real data, and two feedback levels. Nevertheless, some essential limitations of the Balanced Scorecard have also been referred to, such as focusing on learning as the only source for causality, lack of basic guidelines for selecting performance measures, having no method for setting targets to measures, complexity of feedback from the financial perspective to the customer and the internal processes perspectives, and having no consideration of the time lag between the causes and their effects (Dror 2008, p.592). The difficulties and limitations of the Balanced Scored approach are also mentioned by Berry et al., (2009) and Bhagwat \& Sharma (2007) as follows:

- failure to include specific long-term objectives

- failure to relate key measures to performance drivers by means of cause-and effect relationships

- failure to communicate the contents of, and the rationale for, the balanced SCM scorecard

- $\quad$ inaccurate and subjective measures

- lack of participation

- lack of attention to informal controls and organisational context

As such, Balanced Scorecard approach has its own significant limitations, making it difficult to become the foundation for performance measurement and quality excellence.

It is evident from the discussion thus far that currently-proven quality assurance systems, excellence models and award criteria fundamentally suffer from focusing on the enterprise but not the whole supply chain, and not having a holistic, collaboration-centric orientation. Therefore, it is evident that there is a need for change in the quality domain, appearing as extensions, modifications and modernisation efforts for the current assurance and quality excellence ideas, as well as the awarding criteria. For this reason, ideas like extended TQM and modified awards criteria have been in the spotlight for a while.

Additionally, critisism has been put forward towards major supply chain collaboration models, frameworks and initiatives in various aspects. Initial approaches - such as QR (quick response), ECR (efficient consumer response), CRP (continuous replenishment policy), and VMI (vendor-managed inventory) - which lead to CPFR (collaborative planning, forecasting and replenishment) appear as too much material management and logistics oriented (Akyuz\& Gürsoy, 2010). CPFR model by Voluntary Interindustry Commerce Solutions (www.vics.org) contains the concept of collaborative exception management, yet it still does not possess the Quality orientation. The major supply chain framework SCOR (Supply Chain Operations Reference Model by Supply Chain Council (www.supply-chain.org), which provides a strong structural foundation for supply chain 
standardization, communication and collaboration has its drawbacks too. Although it integrates BPR (business process re-engineering), performance measurement and logistics, it has been criticized due to the following aspects, as pointed out by Akyuz \& Gürsoy (2010) and Wang et al., (2010):

- it is silent in the areas of human resources, training, and quality assurance

- it has proved to be impractical as a benchmarking tool and in handling the intangible problems such as cultural conflicts

- it is limited to the representation of one single supply chain, and as such cannot handle multiple channels

- $\quad$ order modification, activities of the collaborative design and CRM are not addressed.

Henceforth, major approaches and initiatives from the supply chain domain appear to be lacking the quality assurance and excellence focus.

None of these efforts- neither from the Quality Management nor the Supply Chain Management points of view- appear to provide a coherent and complete collaborative quality management model with an extended, collaborative focus that allows the supply chain partners in different locations to collectively work on quality tasks at all levels via the Internet. Such a model definitely requires the use of state-of-the-art IT architecture and capabilities to overcome the problems of information islands and to provide application integration among supply chain partners, enabling collaboration and joint quality assurance. This leads one to various more recent efforts of collaborative quality model development seen in the literature, which is to be discussed in the upcoming section.

\section{Further efforts to develop new collaborative quality models}

This section will discuss more recent efforts in the literature to define and develop a supplycentric, collaborative quality platform utilising the current IT technologies.

The conceptual model suggested by Shao et al., (2006) emphasises that partners can collaborate throughout all quality management activities, utilising a web-based, centralised database to provide the backbone and consistency for information- sharing along the entire product lifecycle. The process model developed on top of this conceptual model is supported by a layered, web services-based architecture centered around ERP (Enterprise Resources Planning), CRM (Custumer Relationship Management) and SRM (Supplier Relationship Management) databases. The model also utilises the multi-agent technology, whose main structure is based on 4 main types of collaboration as provided below:

- Quality System Collaboration

- Supplier Collaboration

- Manufacturing Collaboration

- Service Collaboration

The model treats quality functions along the dimensions that cover:

- Quality auditting

- Quality improvement

- Quality assurance

- Quality control

Systemic functions deal with quality system maintenance, quality data reporting, quality planning, quality cost control, continuous improvement and customer satisfaction. Customer-centric functions such as customer service management, after-sales management, 
and supplier-centric functions such as supplier evaluation and selection, are also included in this model.

This approach is in total compliance with the following notions:

- The critical role of a fully integrated enterprise information system, enabling real time data exchange, synchronisation, visibility and sophisticated level of information integration. This idea is fully supported by numerous literature items with regards to ERP, IT-supply chain interaction and enterprise application integration. It is also fully in line with the extended enterprise view, using internal integrity and ERP implementations as the backbone and proceeding with add-ons like CRM and SRM (Akyuz and Rehan, 2009; Xu, 2011).

- The relevance and importance of the use of Web Services and Service Oriented Architectures (SOA) within the supply chain domain, as the most prominent technological enabler of platform-independant, seamless integration of different partner's heterogeneous databases (Rehan \& Akyuz, 2010; Xu, 2011). SOA provides an opportunity to architect new processes enabling multi- organizational collaboration providing platform-independance and web-based integrity (Akyuz, 2008; Rehan \& Akyuz, 2010; Unherkal et al., 2010).

Another more recent collaborative model proposed by Guo et al., (2010) defines the collaborative environment as "the quality chain" and use three layers as basic, technical, and operating environment, highlighting the need for the integration of information, standards and organisation with business requirements, society and culture. Based on this definition, they proceed to develop a multi-dimensional collaborative quality control model for a manufacturing environment with the following characteristics:

- Process quality control in the product lifecycle

- Network organisation management with quality collaboration orientation

- Quality information integration and implementation platform.

An internal quality information integration model is suggested on top of this structure, defining the subsystems and the critical data and information. Note that this model involves integration at every step of the operation, again taking ERP systems as the core and providing the integrity for the following items:

- Design information via CAD/CAPP (Computer aided design/Computer Aided Production Planning) and PDM(Product Data Management) modules

- Production planning and control related information via ERP/MRPII

- Manufacturing and shop floor integrity using MES (Manufacturing Execution Systems)

- Quality-related data from IQS (Internal Quality System)

- Project consolidation and project management-related data and information from the PM (project management) system

- $\quad$ Finance and cost-related information from FM (Finance Management) system

- External customer-related information via CRM.

In this model, the quality-related data, information and knowledge are exchanged to support the needs at operational, tactical and strategic levels. On top of integrity at the master data level (such as drawings and bills of material), the flow of critical information at planning and reporting level (such as market development plans, production plans and schedules, quality plans and financial plans) are exchanged. Also established at this stage are the necessary monitoring and feedback mechanisms. With all these features, the model serves the needs for control, management and assurance dimensions of quality. Once again, 
ERP integrity stands out as the backbone of the platform, with clear definitions for critical data and information flows.

Ho et al., (2009) suggest a co-operative distributed process mining system for quality assurance, highlighting the role and importance of distributed mining as a critical element in the structure. They put forward an XML- based (Extended Mark-up Language) structure including a PME (process mining engine) and a dynamic rule refinement engine. The framework for PME consists of:

- a measurement module, having the practicality of the OLAP (on-line analytical processing ) approach,

- a prediction module to perform proactive quality-related predictions based on real-time data utilising a trained artificial neural network, and

- $\quad$ an improvement module, having a knowledge base for business rules.

This structure is consistent with the business intelligence and data warehousing approaches used in a majority of the ERP platforms, utilising ERP as the single-version-of-truth. Together with the use of OLAP, this structure goes further by enabling prediction and improvement capabilities.

It should be noted here that the recently developed models discussed in this section are quality collaboration platforms focusing on the technological viewpoints, basing on the idea of enterprise application integrity and utilising solid ERP foundations and modular, Webbased layered stuctures. However, these representations still lack the business process reengineering and workflow management viewpoints, and do not contain generic process definitions or clear workflows. Alignment of intra- and inter-company processes and workflows with the underlying technological infrastructure is also essential in establishing collaborating business processes. It should also be noted that the ideas of company culture, benchmarking, excellence and awards- concepts that are essential in quality- do not appear to receive the required attension in this group of models.

\section{Discussion}

In the light of all the inadequecies addressed in section two, the modernisation and extension efforts of total quality management, assurance, excellence and awarding ideas from the Quality domain do not seem to meet the needs of the new supply chain era, even though these efforts did broaden the perspectives on the topic and highlight the importance of supply chain quality. Also, major initiatives and collaborative models from the Supply Chain domain (such as CPFR and SCOR) do not seem to cover the quality management dimension, due to their focus on material management and logistics orientation. Current performance measurement approaches, such as the Balanced Scorecard have been proven to possess their own deficiencies as well, to meet the needs for today's supply chain performance management.

More recent efforts discussed in section three highlight the importance of structural foundation, web services and the layered structures, yet they still lack the ideas of quality excellence and quality systems documentation management. Therefore, it appears that current literature is still in need of further integration of the ideas of collaboration, quality assurance, supply chain, quality system documentation, quality awards\&excellence and supply chain performance measurement using a sound infrastructure based on current IT 
technologies to obtain a coherent, supply-centric, performance- and excellence-oriented collaborative quality model.

In this study, it became evident that such a collaborative quality model should meet the needs of both control, assurance and management aspects of quality. Although these aspects have been defined clearly, there does not seem to be comprehensive, generic process definitions as well as data, information and knowledge requirements to be shared along these dimensions.

The need for and the importance of a sound, jointly used document and knowledge management system appears to be neglected. Similar critisism can also be raised for the human-related, soft aspects, which are always indispensible to quality and collaboration. These soft aspects (such as culture, mutual trust and organisation behaviour) do not appear to receive the attention they have deserved.

In the light of all these ideas, the following can be regarded as the characteristics for an integrative, collaborative quality management model:

- A strong architectural foundation of the partners, with an integrity beyond standard ERP functionality, to cover design, MES, CRM and SRM modules, on top of which quality-related data and information flows can be established.

- Support for operational, tactical and strategic time frames as well as control, assurance and management dimensions of quality.

- Support for collaborative business reengineering tools, allowing continuous improvement, alignment and restructuring among partners' business processes and workflows.

- Critical use of the IT technologies (the Internet, Web services, SOA and mobile services) to assure enterprise application integration among partners.

- Managerial decision support, requiring various data mining, data warehousing and business intelligence techniques layered on top of the integrated systems architecture, aimed at joint managerial decision making and continuous improvement among partners. This also covers the inclusion of predictive and adoptive abilities into the system, requiring the integration of additional tools and techniques, such as artificial intelligence and neural networks.

- Support for a document and knowledge management system to satisfy the requirements regarding the system documentation of multiple quality management systems. This support should naturally handle the requirements such as process documentation, document control and archiving the quality records for multiple quality systems.

- Support for performance measurement and benchmarking among partners. This requires the integration of current the supply chain performance measurement efforts with the literature on quality excellence, including the development of joint measurement \& evaluation processes and development of an extended set of metrics. This would serve for the concerns of supply chain performance measurement literatureas highlighted and comprehensively discussed by Akyuz \& Erkan (2010) and the need to modernise the quality excellence criteria in a supply-centric manner simultaneously.

\section{Conclusion}

This study intended to provide a broad view on collaborative quality management. 
Starting with the changing business pressures and environments, the evolutionary path of Quality Management is discussed in detail. From historical perspective, this evolutionary path indicated a clear transition from an inspection-orientation approach to a collaborative quality management, and definitely revealed the need for a supply centric viewpoint.

In this perspective, inadequecies of the current approaches from both quality management and supply chain domains are addressed. Extension and modernisation efforts witnessed in the quality management domain, as well as the deficiencies and drawbacks of the major approaches from the supply chain domain are discussed in detail, emphasising the need for a supply-centric, collaboration oriented quality understanding. More recent efforts for collaborative quality modelling towards this end highlighted the importance of web-based architectures and strong information system backbones.

In the light of the commonalities and common characteristics observed, a set of requirements for a collaborative, web-enabled, supply-centric quality management model has been gathered.

This study clearly reveals that modelling efforts to obtain a supply-centric, collaborationoriented quality management model are still in progress. Multi-dimensional nature of the problem is already evident, involving both hard and soft aspects, together with a complex set of requirements. The need for further integration of the supply chain and quality management domains is also evident. In this regard, the current literature does not seem to provide a totally comprehensive model as yet. Therefore, collaborative quality management still appears as a promising area of research in terms of the following:

- Conceptual model development

- Identification and standardisation of extended processes \& information flows

- Development of joint "quality excellence" metrics

\section{References}

Akyuz, G.A. (2008). A Survey-based Study on the role of e-procurement in integrating ERP (Enterprise Resources Planning) Systems using e-supply chain. Masters Thesis, Atılim University, Computer Engineering Department, Ankara, Turkey.

Akyuz, G.A. \& Rehan, M. (2009). Requirements for forming an e-supply chain. International Journal of Production Research, Vol.47, No.12, (June 2009), pp. 3265- 3287, ISSN:00207543

Akyuz, G.A. \& Erkan, T.E. (2010). Supply chain performance measurement: a literature review. International Journal of Production Research, Vol. 48, No. 17, (September 2010), pp. 5137-5155, ISSN:0020-7543

Akyuz, G.A. \& Gürsoy, G. (2010). Taxonomy of Collaboration in Supply Chain Management. Proceedings of the VIII. International Logistics and Supply Chain Congress, Logistics Association Publication No.9, pp. 31-44, The Marma Congress Center, Maltepe University, Istanbul, TURKEY, November 4-5, 2010

Berry, A.J. et al. (2009). Emerging themes in management control: a review of recent literature. The British Accounting Review, Vol. 41, No.1, (March 2009), pp.2-20, ISSN: 0890-8389 
Bhagwat, R. \& Sharma, M.K. (2007). Performance Measurement of Supply Chain Management: A Balanced Scorecard Approach. Computers and Industrial Engineering, Vol. 53, No.1, (August 2007), pp.43-62, ISSN: 0360-8352

Dror, S. (2008). The Balanced Scorecard versus quality award models as strategic frameworks. Total Quality Management \& Business Excellence, Vol. 19, No. 6, (June 2008), pp. 583- 593, ISSN: 1478-3363

Flynn, B.B. \& Flynn E.J. (2005). Synergies between supply chain management and quality management: emerging implications. International Journal of Production Research, Vol. 43, No. 16, (August 2005), pp. 3421-3436, ISSN: 0020-7543

Foster, S.T. (2008). Towards an understanding of supply chain quality management. Journal of Operations Management, Vol. 26, No.4, (July 2008), pp. 461-467, ISSN: 0272-6963

Foster, S.T. \& Ogden, J. (2008). On differences in how operations and supply chain managers approach quality management. International Journal of Production Research, Vol. 46, No. 24, (December 2008), pp. 6945-6961, ISSN: 0020-7543

Guo, W., et al. (2010). Research on Multi-dimension Model of Collaborative Quality Control in Manufacturing Network. Proceedings of International Conference of Information Science and Management Engineering (ISME), pp. 331-336, ISBN: 978-1-4244-7669-5, Shaanxi, China, August 2010

Ho, G. T. S. et al. (2009). Development of a cooperative distributed process mining system for quality assurance. International Journal of Production Research, Vol. 47, No. 4, (January 2009), pp. 883-918, ISSN 0020-7543

Kanji, G.K. (2001). Forces of excellence in Kanji's Business Excellence Model. Total Quality Management E Business Excellence, Vol. 12, No. 2, (March 2001), pp. 259-272, ISSN: 0954-4127

Kanji, G.K. \& Wong, A. (1999). Business Excellence model for supply chain management. Total Quality Management \& Business Excellence, Vol. 10, No: 8, (December 1999), pp.1147-1168, ISSN:0954-4127

Kaynak, H. (2003). The relationship between total quality management practices and their effects on firm performance. Journal of Operations Management, Vol. 21, No. 4, (July 2003), pp. 405-435, ISSN: 0272-6963

Kaynak, H. \& Hartley, J. (2008). A replication and extension of quality management into the supply chain. Journal of Operations Management, Vol. 26, No.4, (July 2008), pp. 468489, ISSN:0272-6963

Kuei, C. et al. (2008). Implementing supply chain quality management. Total Quality Management \& Business Excellence, Vol. 19, No. 11, (November 2008), pp. 1127-1141, ISSN: $1478-3363$

Lee, S.M. et al. (2006). Modernization of the Malcolm Baldrige National Quality Award. International Journal of Production Research, Vol. 44, No. 23, (December 2006), pp. 5089- 5106, ISSN: 0020-7543

Matthews, C.R. (2006). Linking the Supply Chain to TQM, Quality Progress, American Society for Quality, Vol. 39, No. 11, (November 2006), pp 29-35, ISSN: 0033-524X

Rehan, M. \& Akyuz, G.A. (2010). EAI (Enterprise Application Integration), SOA (Service Oriented Architectures) and its relevance to e-supply chain formation. African 
Journal of Business Management, Vol. 4, No. 13, (October 2010), pp. 2604-2614, ISSN 1993-8233.

Robinson, C.J. \& Malhotra, M.K. (2005). Defining the concept of supply chain quality management and its relevance to academic and industrial practice. International Journal of Production Economics, Vol. 96, No. 3, (June 2005), pp.315-337, ISSN: 09255273

Rodrigues, C.A. (2007). The quality organisation: A conceptual Framework. Total Quality Management and Business Excellence, Vol. 18, No. 7, (September 2007), pp. 697-713, ISSN: $1478-3371$

Romano, P. (2002). Impact of supply chain sensitivity to quality certification on quality management practices and performances. Total Quality Management, Vol.13, No.7, (November 2002), pp. 981-1000, ISSN: 0954-4127

Supply Chain Council, SCOR Version 10.0, Supply Chain Operations Reference Model, Accessed 15 March 2011, Available From: <http://supply-chain.org/f/SCOROverview-Web.pdf>

Shao, X-Y. et al. (2006). A Web enabled Quality Management System. Journal of Manufacturing Systems, Vol. 25, No.2, pp. 95-107, ISSN: 0278-6125

Soltani, E. et al. (2011). Quality Performance in a global supply chain: finding out the weak link. International Journal of Production Research, Vol. 49, No. 1, (January 2011), pp. 269-293. ISSN: 0020-7543

Sroufe, R. \& Curkovic, S. (2008). An examination of ISO 9000:2000 and supply chain quality assurance. Journal of operations management, Vol. 26, No.4, (July 2008), 503-520, ISSN: 0272-6963

Unhelkar, B. et al. (2010). Collaborative Business Process Engineering and Global Organisations. Business Science Reference, ISBN: 978-1-60566-690-7, Hershey, New York

VICS, Voluntary Interindustry Commerce Standards (2004). Collaborative Planning, Forecasting and Replenishment (CPFR) Model Overview, May 2004. Accessed: 5 September 2010, Available from:

<http://www.vics.org/docs/committees/cpfr/CPFR_Overview_US-A4.pdf>

Wang, W.Y.C., et al. (2010). Aligning business process reengineering in implementing global supply chain systems by SCOR model. International Journal of Production Research, Vol.48, No.19, (October 2010), pp. 5647-5669, ISSN: 0020-7543

Williams, R. et al. (2006). Quality Management: The New Challenges. Total Quality Management \& Business Excellence, Vol. 17, No. 10, (December 2006), pp. 1273-1280, ISSN: $1478-3371$

Wong, A. (2003). Achieving supply chain management excellence, Total Quality Management, Vol. 14, No. 2, pp. 151-159, ISSN: 1478-3363

$\mathrm{Xu}$, L.D. (2011). Information Architecture for supply chain quality management. International Journal of Production Research, Vol. 49, No. 1, (January 2011), pp.183-198, ISSN: 00207543.

Yan, J. et al. (2010). Ontology of collaborative supply chain for quality management. World Academy of Science, Engineering and Technology, Vol. 64, (April 2010), pp. 319-324, ISSN: $2010-3778$ 
Zsidisin, G.A. \& Ritchie, B. (2009). Supply Chain Risk: A Handbook of Assessment, Management and Performance (XVI), Springer, ISBN: 978-0-387-79933-9, International Series in Operations Research and Management Science, New York, USA 


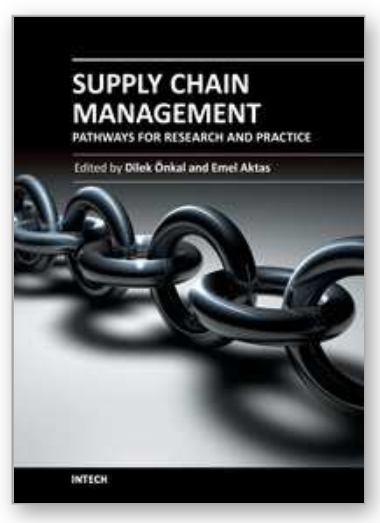

\author{
Supply Chain Management - Pathways for Research and Practice \\ Edited by Prof. Dilek Onkal
}

ISBN 978-953-307-294-4

Hard cover, 234 pages

Publisher InTech

Published online 01, August, 2011

Published in print edition August, 2011

Challenges faced by supply chains appear to be growing exponentially under the demands of increasingly complex business environments confronting the decision makers. The world we live in now operates under interconnected economies that put extra pressure on supply chains to fulfil ever-demanding customer preferences. Relative attractiveness of manufacturing as well as consumption locations changes very rapidly, which in consequence alters the economies of large scale production. Coupled with the recent economic swings, supply chains in every country are obliged to survive with substantially squeezed margins. In this book, we tried to compile a selection of papers focusing on a wide range of problems in the supply chain domain. Each chapter offers important insights into understanding these problems as well as approaches to attaining effective solutions.

\title{
How to reference
}

In order to correctly reference this scholarly work, feel free to copy and paste the following:

Goknur Arzu Akyuz (2011). Collaborative Quality Management, Supply Chain Management - Pathways for Research and Practice, Prof. Dilek Onkal (Ed.), ISBN: 978-953-307-294-4, InTech, Available from: http://www.intechopen.com/books/supply-chain-management-pathways-for-research-andpractice/collaborative-quality-management

\section{INTECH}

open science | open minds

\author{
InTech Europe \\ University Campus STeP Ri \\ Slavka Krautzeka 83/A \\ 51000 Rijeka, Croatia \\ Phone: +385 (51) 770447 \\ Fax: +385 (51) 686166 \\ www.intechopen.com
}

\author{
InTech China \\ Unit 405, Office Block, Hotel Equatorial Shanghai \\ No.65, Yan An Road (West), Shanghai, 200040, China \\ 中国上海市延安西路65号上海国际贵都大饭店办公楼405单元 \\ Phone: +86-21-62489820 \\ Fax: $+86-21-62489821$
}


(C) 2011 The Author(s). Licensee IntechOpen. This chapter is distributed under the terms of the Creative Commons Attribution-NonCommercialShareAlike-3.0 License, which permits use, distribution and reproduction for non-commercial purposes, provided the original is properly cited and derivative works building on this content are distributed under the same license. 